\title{
Design and Evaluation of Novel Primers for the Detection of Genes Encoding Diverse Enzymes of Methylotrophy and Autotrophy
}

\author{
WEI-LIAN HUNG ${ }^{1}$, WILLIAM G. WADE ${ }^{1 \star}$, YIN CHEN ${ }^{2}$, DONOVAN P. KELLY² and ANN P. WOOD ${ }^{3}$ \\ ${ }^{1}$ King's College London Dental Institute, Microbiology, Guy’s Campus, London, SE1 9RT, UK \\ ${ }^{2}$ School of Life Sciences, University of Warwick, Coventry CV4 7AL, UK \\ ${ }^{3}$ Department of Biochemistry, King's College London, Henriette Raphael House, Guy's Campus, London SE1 1UL, UK
}

Received 18 January 2012, revised 10 February 2012, accepted 10 February 2012

\begin{abstract}
The phylogenetic significance of the diversity of key enzymes of methylotrophic and autotrophic metabolism is discussed. Primers for these key enzymes were designed using gene sequences encoding methanol dehydrogenase ( $m x a F$; using subsets from database sequences for 22 Bacteria), hydroxypyruvate reductase ( $h p r ; 36$ sequences), methylamine dehydrogenase (mauA; 12 sequences), methanesulfonate monooxygenase ( $m s m A$; four sequences), and the $c c b L$ and $c b b M$ genes of ribulose bisphosphate carboxylase (26 and 23 sequences). These were effective in amplifying the correct gene products for the target genes in reference organisms and in test organisms not previously shown to contain the genes, as well as in some methylotrophic Proteobacteria isolated from the human mouth. The availability of the new primers increases the probability of detecting diverse examples of the genes encoding these key enzymes both in natural populations and in isolated bacterial strains.
\end{abstract}

Key words: Proteobacteria, primers, methylotrophy, autotrophy, methanol dehydrogenase, hydroxypyruvate reductase, methylamine dehydrogenase, RuBisCO

List of abbreviations: $\mathrm{C}_{1}$ - one-carbon, RuBisCO - ribulose bisphosphate carboxyase/oxygenase, $c b b L$ - gene encoding the large subunit of type I RuBisCO, CbbL - amino acid sequence encoded by $c b b L, c b b M$ - gene encoding the large subunit of type II RuBisCO, HPR - hydroxypyruvate reductase, $h p r$ - gene encoding HPR, Hpr - amino acid sequence encoded by $h p r$, HPS - 3-hexulose 6-phosphate synthase, Hps - gene encoding HPS, Hps - amino acid sequence encoded by $h p s, \mathrm{MDH}$ - methanol dehydrogenase, $m x a F$ - gene encoding the large subunit of $\mathrm{MDH}, \mathrm{MxaF}$ - amino acid sequence encoded by mxaF, MMA - methylamine, MADH - methylamine dehydrogenase, mauA - gene encoding the small subunit of MADH, MauA - amino acid sequence encoded by mauA, MSA - methanesulfonate, MSAMO - methanesulfonate monooxygenase, $m s m A$ - gene encoding the $\alpha$-subunit of the hydroxylase of MSAMO, MsmA - amino acid sequence encoded by $m s m A, \mathrm{~T}_{\mathrm{m}}$ - DNA melting point

\section{Introduction}

Methylotrophic bacteria use $\mathrm{C}_{1}$-compounds (including methanol, methylamine and methanesulfonate) to provide energy and carbon for growth (Kelly and Murrell 1996; Lidstrom, 2006). Their metabolic processes have global significance in environmental bioremediation, climate homeostasis, and in the human body (Murrell and Kelly, 1996; Kelly and Wood, 2010; Wood and Kelly, 2010; Wood et al., 2010). They occur in diverse habitats including Antarctica, ubiquitously in soil, marine and freshwater environments, and in the human microbiome (Anesti et al., 2004, 2005; Moosvi et al., 2005a, b; Neufeld et al., 2007; Boden et al., 200 8; Hung etal., 2011). A powerful tool in molecular microbial ecology and biochemistry is the use of oli- gonucleotide primers to probe for genes encoding enzymes diagnostic of specific metabolic processes, and this approach has enabled detection of methylotrophic bacteria in diverse habitats. Primers for methanol dehydrogenase, methylamine dehydrogenase, and methanesulfonate monooxygenase, have all been described in recent years. The most widely used have been the primers to detect $\mathrm{MDH}$ developed by McDonald and Murrell (1997), and few variations on those original primers have been reported (Moosvi et al., 2005b; Neufeld et al., 2007). Only a few examples of primers for other genes of $\mathrm{C}_{1}$-metabolism have been published, such as those for MADH (Neufeld et al., 2007), and two primer sets for MSAMO, producing either 783 or $233 \mathrm{bp}$ products (Baxter et al., 2002; Moosvi et al., 2005b). One outcome of using molecular methods to detect and

* Corresponding author: W.G. Wade, King's College London, Dental Institute, Microbiology, Guy's Campus, London, SE1 9RT, UK; e-mail: william.wade@kcl.ac.uk 
subsequently sequence the genes encoding $\mathrm{MDH}$ has been the demonstration of significant diversity among the $\mathrm{MDH}$ genes and enzymes of different methylotrophs (Fesefeldt and Gliesche 1997; Anesti et al., 2004; Neufeld et al., 2007; Vorob'ev et al., 2009). While degeneracy of the nucleotide sequences of genes encoding MDH is expected because of the variety of codons encoding the same amino acid, significant diversity is also found in the encoded MDH and MADH proteins from different Bacteria (e.g., Fesefeldt and Gliesche 1997; Chistoserdov 2001; Neufeld et al., 2007; Vorob’ev et al., 2009), in which the nucleotide and amino acid sequences can deviate by $20 \%$ or more. The active site of the MxaF subunit of MDH appears, however, to be highly conserved, and the primers targeting that region have been successful in detecting quite divergent genes encoding MxaF. In order both to increase the likelihood of detecting variant forms of $\mathrm{MDH}$, and to increase the range and specificity of probes for $\mathrm{MDH}, \mathrm{MADH}$ and MSAMO, we set out to design new primers for $m x a F, m a u A$ and $m s m A$, as well as primers for genes encoding enzymes essential for assimilatory pathways for $\mathrm{C}_{1}$-compounds (the serine and ribulose monophosphate cycles), namely $h p r$ for hydroxypyruvate reductase, and $h p s$ for hexulose phosphate synthase. In addition, primers were designed for $c b b L$ and $c b b M$, encoding the subunits of the key enzyme of the Calvin Cycle (RuBisCO), essential for autotrophic growth in some facultative methylotrophs. Our aim was to use the phylogeny of the genes encoding key enzymes of $\mathrm{C}_{1}$-metabolism to guide the design of PCR primers for the detection of these genes, and to increase both the power and specificity of primers in the armoury of the molecular microbial ecologist and biochemist.

\section{Experimental}

\section{Materials and Methods}

\section{Design of primers based on GenBank database} sequences encoding enzymes of methylotrophy and autotrophy from Bacteria in various phylogenetic groups. Nucleotide sequences of $c b b L, c b b M, h p r, h p s$, $m x a F, m s m A$, and mauA genes of Bacteria from the phylogenetic groups detailed in the Results and Discussion section were obtained from the GenBank database, and aligned using ClustalW within the BioEdit suite (Hall 1999). Neighbor-joining phylogenetic trees were constructed from amino acid sequences to guide primer design, using MEGA4 (Tamura et al., 2007). Nucleotide alignments were manually inspected for regions of homology and multiple degenerate primers were designed for clusters of related sequences for each gene, with $\mathrm{G}+\mathrm{C}$ contents of between 45 and
$55 \%$. Self-complementarity and hairpin formation was avoided in primer design, and degeneracy introduced to a maximum of three bases per primer. Primers were synthesized by MWG Biotech (London, UK). For each gene, a panel of reference strains was assembled and the specificity of the primers checked using PCR.

Isolation of DNA and PCR protocol. DNA was extracted from strains by means of the GenElute bacterial genomic DNA kit (Sigma-Aldrich Company Ltd., Poole, Dorset, UK) using the manufacturer's protocol for Gram-positive Bacteria. For PCR, DNA template $(1 \mu \mathrm{L})$ and $5 \mathrm{pmol}$ of each primer were added to $23 \mu \mathrm{L}$ Reddy Mix PCR Master Mix (ABGene, Epsom, Surrey, UK). The PCR cycle conditions were: denaturation at $94^{\circ} \mathrm{C}$ for $15 \mathrm{~min}$, then 30 cycles at $94^{\circ} \mathrm{C}$ for $45 \mathrm{~s}, 54^{\circ} \mathrm{C}$ for $45 \mathrm{~s}$, and $72^{\circ} \mathrm{C}$ for $90 \mathrm{~s}$, followed by one cycle of elongation for $15 \mathrm{~min}$ at $72^{\circ} \mathrm{C}$. Amplicons were bi-directionally sequenced by means of the BigDye Terminator 3.1 cycle sequencing kit (Applied Biosystems) with the primers used for the original PCRs using a 3730xl DNA Analyzer (Applied Biosystems) according to the manufacturer's instructions, and sequences assembled in BioEdit. The predicted annealing temperatures for the primer pairs used was estimated from their mean $\mathrm{T}_{\mathrm{m}}$ values, and ranged over $50-60^{\circ} \mathrm{C}$. Use of the primers with DNA from the reference bacterial strains (see below) was tested within the range $42-61^{\circ} \mathrm{C}$ for different primer pairs. The optimum for the reference strains was taken as $54^{\circ} \mathrm{C}$. Further detail is given in the Results and Discussion.

Reference bacterial strains cultured to test the specificity of the primers generated in this study. The following strains were cultured on agar or liquid media, incubated aerobically at $26^{\circ}$ or $30^{\circ} \mathrm{C}$, using the conditions and media specified for the organisms on the website of the Deutsche Sammlung von Mikroorganismen und Zellkuturen (http://www.dsmz.de), or as described below: Methylobacterium extorquens AM1 (DSM 1338), Methylococcus capsulatus Bath (ATCC 33009; Warwick collection, grown at $45^{\circ} \mathrm{C}$, on ATCC medium 1309: http://www.lgcstandards-atcc.org/Attachments/2554. pdf), and Xanthomonas campestris pv. campestris (DSM 3586) for mxaF; Polaromonas naphthalenivorans CJ2 (DSM 15660) and Ralstonia eutropha H16 (DSM 428) for hpr; Methylobacterium extorquens AM1 and Methylobacillus flagellatus KT (DSM 6875) for mauA; Afipia felis 25E1 (Ann Wood collection; cultured as described by Moosvi et al., 2005a) for $m s m A$; Burkholderia xenovorans LB400 (DSM 17367), Ralstonia eutropha H16 and Methylococcus capsulatus Bath for cbbL; and Rhodobacter sphaeroides 2.4.1 (DSM 158), Polaromonas naphthalenivorans CJ2 and Thiomicrospira kueneni (DSM 12350) for $c b b M$.

Bacterial strains probed using the new primers. Six methylotrophic bacterial strains from the War- 
wick Collection, known to express activities of $\mathrm{MDH}$, HPR or RuBisCO, were tested to determine if the target genes could be detected in their DNA using the new mxaF, $h p r, c b b L$ and $c b b M$ primers. These were Aminobacter aminovorans MA (ATCC 23819), Xanthobacter tagetidis TagT2C (DSM 11105), Methylocella silvestris BL2 (DSM 15510), Methylocystis sporium strain 5 (ATCC 35069), Methylocystis parvus OBBP (ATCC 35066), and Methylosinus trichosporium OB3b (ATCC 35070).

In addition, eleven strains of methylotrophic bacteria previously isolated from the mouth (Hung et al., 2011) were tested for the presence of the target genes by PCR using the new msmA, mxaF, hpr, cbbL and $c b b M$ primers. Six of these were Actinobacteria (Brevibacterium, Gordonia, Leifsonia, Microbacterium, Micrococcus, Rhodococcus,) and five were Alpha-, Beta- and Gammaproteobacteria (Achromobacter, Klebsiella, Methylobacterium, Pseudomonas, Ralstonia). The culture and properties of all these were described previously (Hung et al., 2011).

\section{Results and Discussion}

Phylogenetic significance of the diversity of genes encoding enzymes of autotrophy and methylotrophy. Nucleotide sequence diversity was expected among genes encoding the same protein in different organisms because the same amino acid can be encoded by more than one triplet of nucleotides (e.g. six different synonymous codons exist for each of arginine, leucine and serine). For this reason, comparison of the encoded amino acid sequences was a more useful means of making comparisons of functional genes among different Bacteria. In the case of the genes considered by us, however, considerable diversity also existed among the encoded proteins, as was initially observed for $\mathrm{MDH}$ and MADH from different Proteobacteria (McDonald and Murrell 1997; Chistoserdov 2001; Neufeld et al., 2007). We found that this diversity applied to the amino acid sequences for all the strains we used for the design of primers for the genes encoding CbbL, CbbM, Hpr, MauA, and MxaF (Fig. 1-5). This diversity was

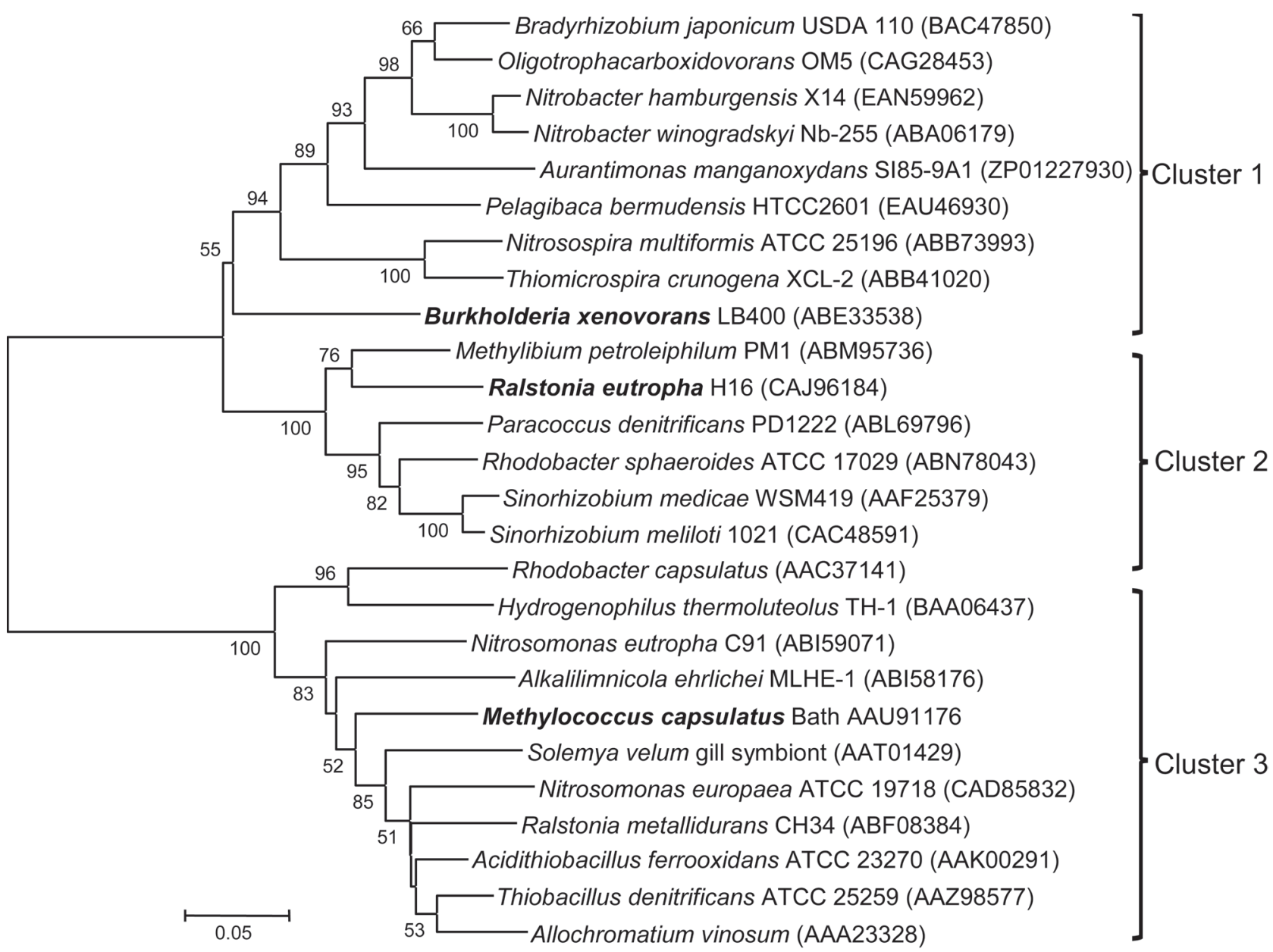

Fig. 1. Phylogenetic tree based on CbbL amino acid sequence comparisons constructed using the neighbor-joining method with the Poisson correction from an alignment of 470 amino acids. Numbers represent bootstrap values for each branch based on data for 1000 trees. Accession numbers for amino acid sequences are given for each strain. Scale bar shows number of amino acid substitutions per site. Organisms shown in bold type were reference strains used to test the primers. 


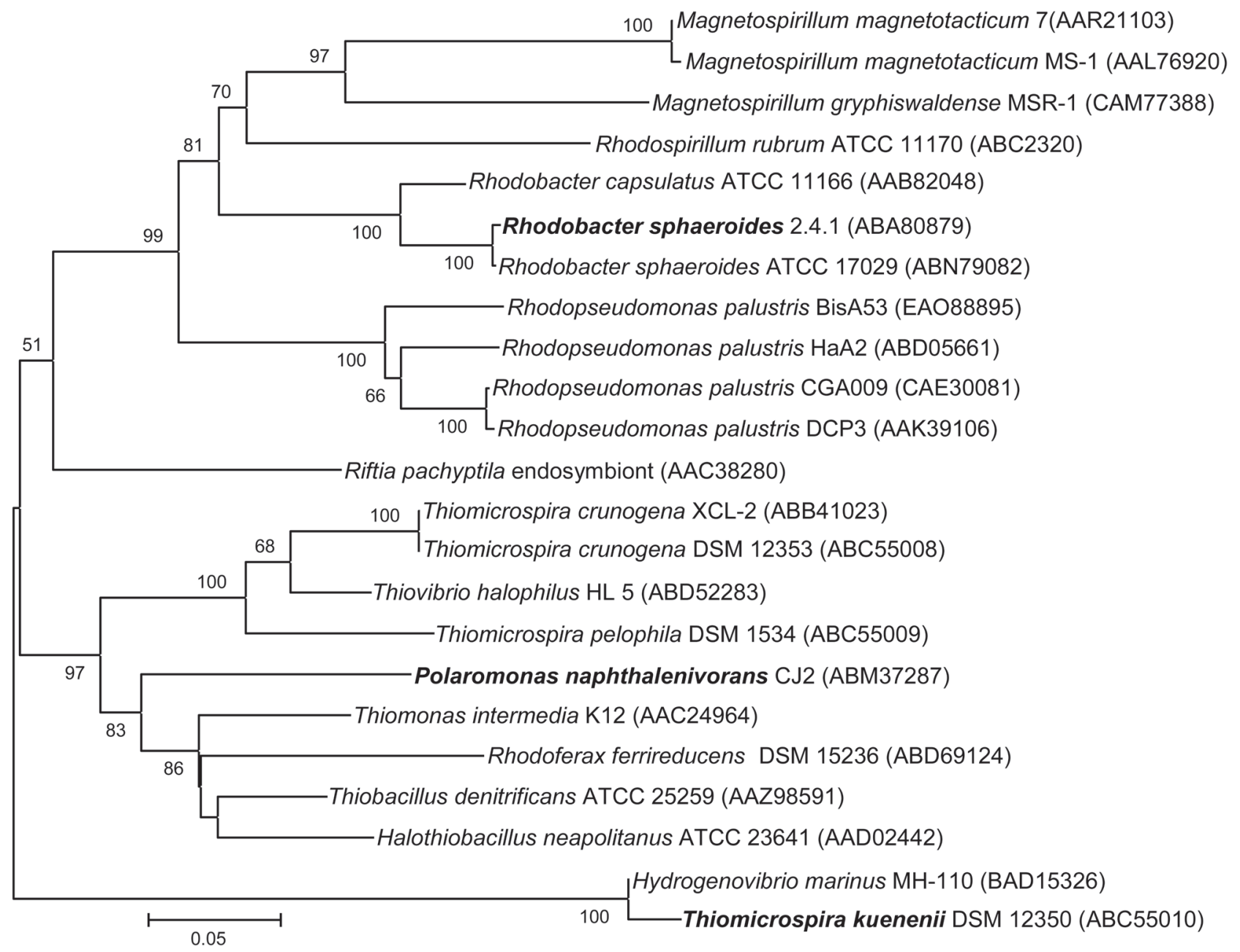

Fig. 2. Phylogenetic tree based on CbbM amino acid sequence comparisons constructed from an alignment of 457 amino acids. [All other details as in legend to Fig. 1]

well-illustrated by the CbbL tree in which three distinct clusters could be identified (Fig. 1). Similarly, clustering into two or more groups was seen for the CbbM, Hpr, MauA, and MxaF trees (Fig. 2-5), with further probable subdivision into several clades, between which considerable sequence diversity was seen. The distribution of sequences from different Bacteria was frequently not congruent with their 16S rRNA gene sequence phylogeny, with distinct clusters or groups containing mixtures of Alpha-Beta- and Gammaproteobacteria. This was particularly marked in the case of cluster 3 of the CbbL tree, which contained examples of Alpha-, Betaand Gammaproteobacteria (Fig. 1: e.g. Rhodobacter, Thiobacillus, Methylococcus); and for CbbM and HPr (in which considerable 'sub-clustering' was seen) with different proteobacterial genera exhibiting highly similar proteins (Fig. 2: e.g. Rhodoferax, Thiobacillus, and Halothiobacillus; Fig. 3: e.g. Acidiphilium, Methylibium). McDonald and Murrell (1997) originally observed consistency between proteobacterial groups and the mxaFencoded amino acid sequences, which was largely supported by our analysis although with some occur- rence of both Alpha- and Beta- and Gammaproteobacteria within the same cluster (Fig. 5: e.g. Granulibacter, Methylophaga and Paracoccus). Similarly, there was clustering of Beta- and Gammaproteobacteria in our MauA tree (Methylophaga, Methylophilus, Methylobacillus), with Alphaproteobacteria forming a separate cluster (Fig. 4: Paracoccus, Methylobacterium and Hyphomicrobium). Clustering of similar amino acid sequences for genera from different phylogenetic classes suggested that horizontal gene transfer (HGT) had taken place in the acquisition of genes for at least some of these functional enzymes (Kalyuzhnaya et al., 2008), while clusters of members the same proteobacterial group with similar proteins was consistent with retention of an ancestral form. Using $\mathrm{MxaF}$ as an example (Fig. 5), the proteins from Methylophaga and Methylococcus show only 43\% sequence identity to that from Xanthobacter (all being Gammaproteobacteria), but show $70-73 \%$ identity to that from Paracoccus (Alphaproteobacteria), highly indicative of HGT having occurred.

Designing the primers. For primer design, groups of sequences from within the amino acid trees (Fig. 1-5) 


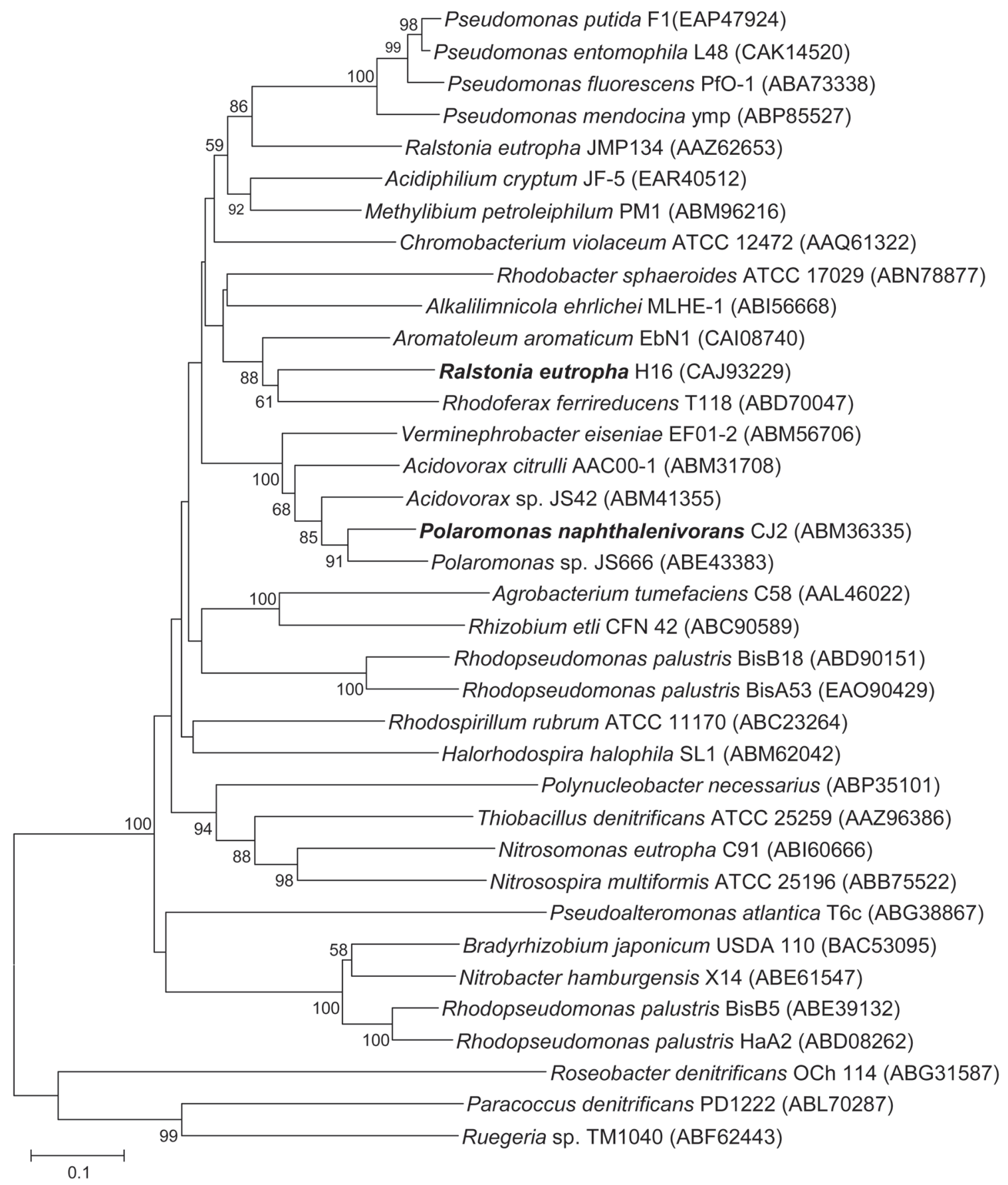

Fig. 3. Phylogenetic tree based on Hpr amino acid sequence comparisons constructed from an alignment of 315 amino acids.

[All other details as in legend to Fig. 1]

were selected to enable targeting of the presumed diverse genes encoding the enzyme proteins. For $c b b L$, for example, nucleotide sequences were retrieved for the three clusters of the 26 strains of Proteobacteria (Fig. 1). Sub-alignments were created for each of the three clusters, and there was sufficient sequence homology between strains within the clusters to allow design of cluster-specific degenerate PCR primers. Primers were designed in a similar way for the genes encoding the other clusters for $23 \mathrm{cbbM}, 36 \mathrm{hpr}$, and $12 \mathrm{mauA}$ nucleotide sequences. All sequences found for these genes were from strains of Proteobacteria, except for mauA for which one sequence was from the verrucomicrobium, Methylacidiphilum infernorum.

Amino acid sequences encoded by the $22 \mathrm{mxaF}$ genes subdivided into three, possibly four, clusters or clades (Fig. 5) and primers were designed for the Granulibacter-Bradyrhizobium group (mxaF I), and for the Xanthobacter-Xanthomonas clade (mxaF III). For the Hyphomicrobium-Methylobacillus clade(s), we found that the primers designed by McDonald and Murrell (1997) and Neufeld et al., (2007) gave good 


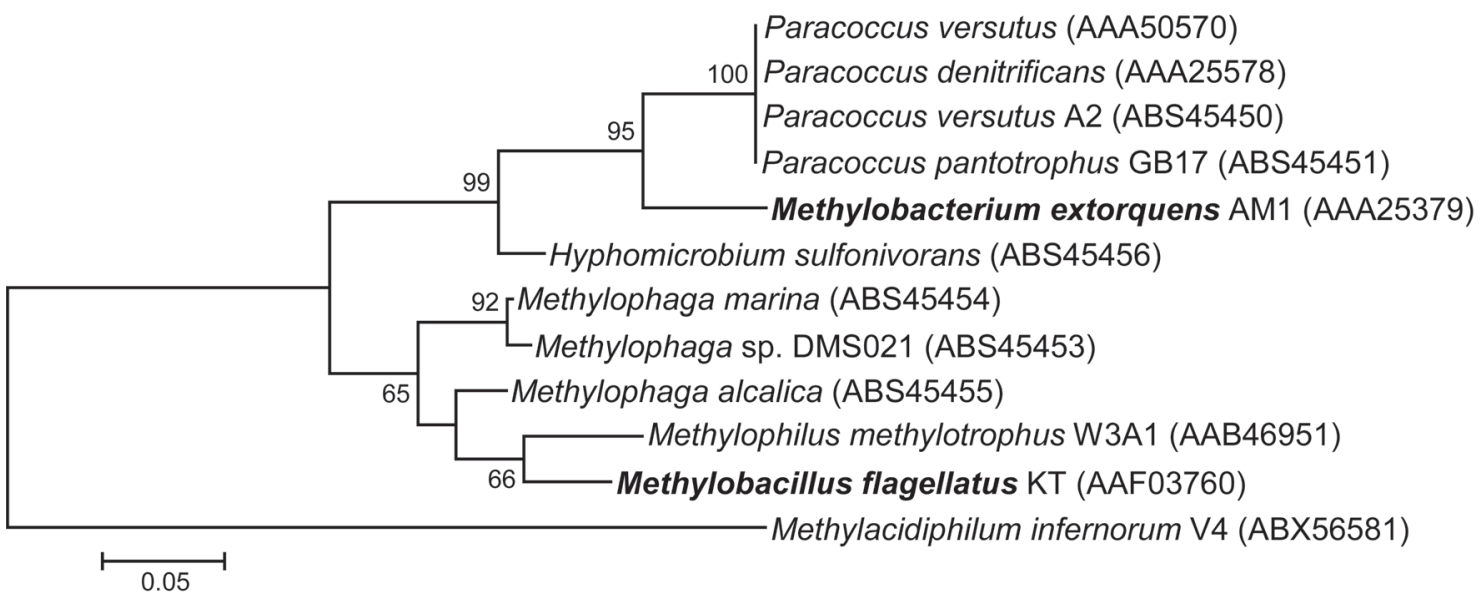

Fig. 4. Phylogenetic tree based on MauA amino acid sequence comparisons constructed from an alignment of 91 amino acids. [All other details as in legend to Fig. 1]

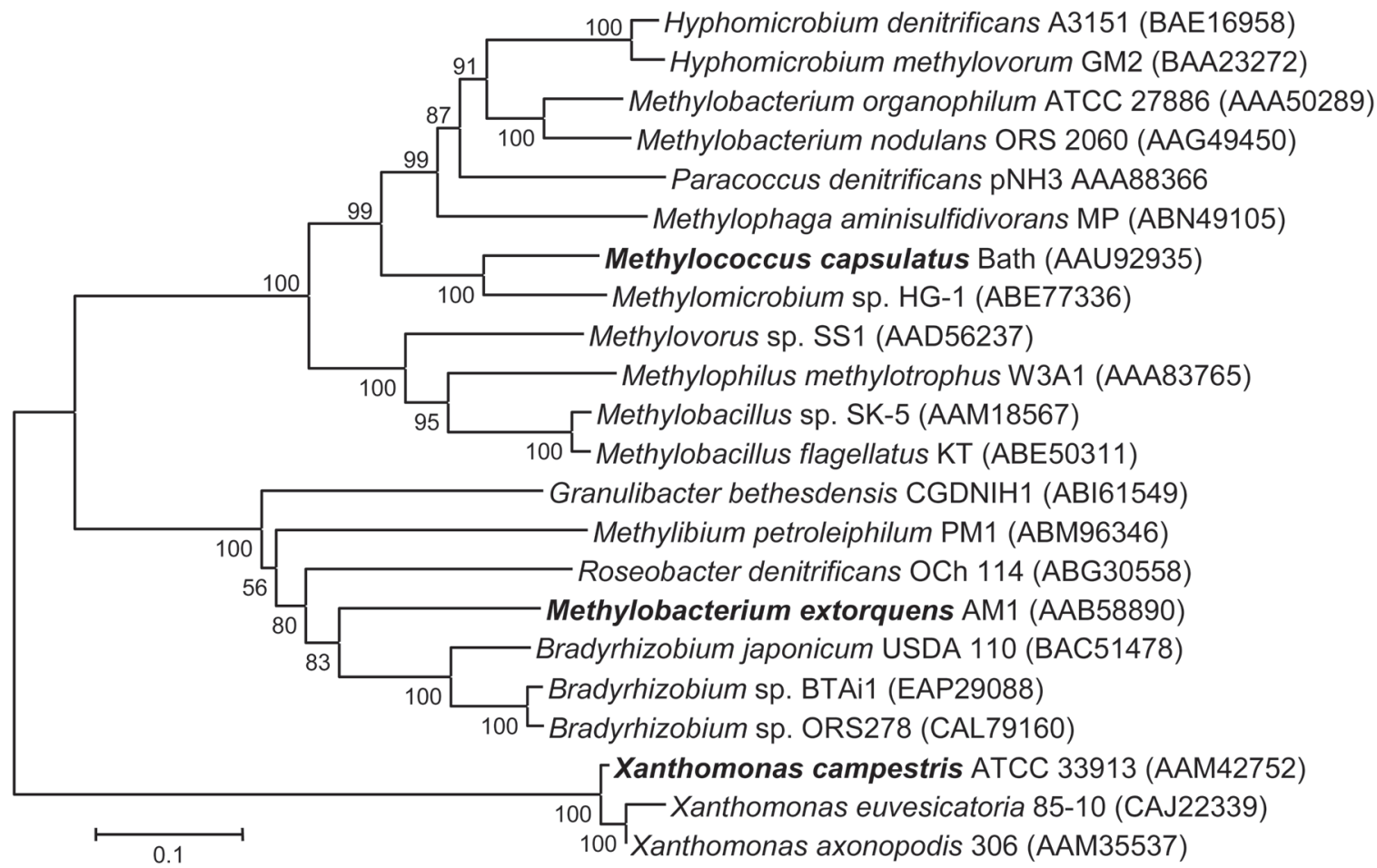

Fig. 5. Phylogenetic tree based on MxaF amino acid sequence comparisons constructed from an alignment of 155 amino acids. [All other details as in legend to Fig. 1]

matches to these sequences (differing in the main by $0-2$ mismatches, and by $3-4$ only in three of 36 primer matches for the 12 sequences). This contrasted with up to 12 mismatches for the other two groups. Consequently, it was unnecessary to design new primers for Hyphomicrobium-Methylobacillus group, and the available primers were used as mxaF II.

For $m s m A$, four alphaproteobacterial GenBank sequences were used for primer design (Methylobacterium nodulans, ZP_02124686; Afipia felis, ABO41866; Methylosulfonomonas methylovora, AAD26619; and Marinosulfonomonas methylotropha, AAK84301). These were quite divergent, showing only $83-87 \%$ encoded amino acid sequence similarity to each other, but enabled nine primers to be designed.

Attempts to design primers for the hexulose phosphate synthase gene, $h p s$, were unsuccessful. Database sequences were compared for 12 species of eight genera, all members of the Gammaproteobacteria (Escherichia, Haemophilus, Klebsiella, Mannheimia, Methylococcus, Methylomonas, Shigella and Vibrio), whose amino acid sequences fell into four distinct clades on a tree, but did not allow for the design of useful primers: this may have reflected the diversity of function known for Hps, which 
is an assimilatory enzyme of RuMP-pathway methylotrophs, but functions for formaldehyde detoxification in non-methylotrophs (Kato et al., 2006), and possibly for pentose synthesis in other Bacteria and Archaea (e.g. Yurimoto et al., 2009).

Testing the new primers with DNA from the reference strains. A total of 100 primers were designed for the functional genes of RuBisCO (cbbL I, II, III and $c b b M$ I, II), MDH (mxaF I, II), HPR (hpr I, II), MADH ( $m a u A$ I, II), and MSAMO ( $m s m A)$, all of which were tested in various combinations against the relevant reference organisms (see Materials and Methods and Fig. 1-5). Most generated the predicted size product, and amplicons were sequenced to confirm that the correct gene had been amplified. A reduced set of 44 primers yielding the correct amplicons was selected for recommended use (Table I). Pairs of these were tested in various combinations at different annealing temperatures $\left(42-61^{\circ} \mathrm{C}\right)$ : for example, ten $c b b L$ I pairs tested with Burkholderia xenovorans DNA gave the correct-sized products at two or more of five temperatures between $45^{\circ}$ and $57^{\circ} \mathrm{C}$, nine of them at $54^{\circ} \mathrm{C}$. Similarly, four $c b b L$ II and nine $c b b L$ III primer pairs gave products over the same range with Ralstonia eutropha and Methylococcus capsulatus at $54^{\circ} \mathrm{C}$. For primer pairs designed for the other genes, the optimum was also $54^{\circ} \mathrm{C}$, with few reactions at lower or higher temperatures. This established $54^{\circ} \mathrm{C}$ as the most likely temperature for annealing with the primer pairs.

Sequencing of the amplicons of the predicted size generated by the new primers with the reference Bacteria showed 99-100\% sequence identity to the expected products (Table II).

Testing the methylotrophic strains from the human mouth with the primers. The primers were tested against DNA from the eleven methylotrophs isolated from the mouth and described in detail by Hung et al. (2011). Six of these were Actinobacteria, none of which gave the predicted PCR products with any of the primers. As the design of the functional primers was based on proteobacterial sequences, it seems that they were not suitable for detecting the corresponding genes in the Actinobacteria. Alternatively, those strains may use different metabolic pathways: information on methylotrophy in Gram-positive organisms is relatively limited (Arfman et al., 1992), as methylotrophic metabolism research has mainly focused on pathways in Gram-negative organisms. For example, methanol oxidation by a thermophilic Bacillus uses an NAD-dependent $\mathrm{MDH}$ unrelated to the proteobacterial PQQ enzyme (de Vries, 1992); and a Mycobacterium strain used a novel methanol-oxidizing enzyme for its methylotrophic growth (Park et al., 2011). Also, methylamine dehydrogenase is not a unique diagnostic enzyme for methylamine-degraders, as
Table I

PCR primers for the amplification of $c b b L, c b b M, h p r, m x a F$, $m s m A$, and mauA genes (5'-3'; F forward primer; R reverse primer)

\begin{tabular}{|c|c|c|}
\hline Target gene & Primer & Sequence \\
\hline \multirow[t]{8}{*}{$c b b L$} & cbbLI-310F & TGGACCRYVGTVTGGACCGA \\
\hline & cbbLI-763F & TTYATGCRYTGGCGCGAYCG \\
\hline & cbbLI-1331R & SGTGCCRCCRCCRAAYTGCA \\
\hline & cbbLII-446F & TCGCCTTCSAGYTTGCCVAC \\
\hline & cbbLII-1254R & GTGTGGACCGAYCKSCTGAC \\
\hline & cbbLIII-354F & GGYAACGTVTTCGGMTTYAA \\
\hline & cbbLIII-615F & CAGCCNTTCATGCGYTGGMG \\
\hline & cbbLIII-909R & ACVCGGAAGTGRATRCCGTG \\
\hline \multirow[t]{7}{*}{$c b b M$} & cbbMI-899F & TSATGAAGATCGCSTAYCCS \\
\hline & cbbMI-1062F & GCAACAACCAGGGCATGGGC \\
\hline & cbbMI-1472R & TCGSCRAAGGTYTCVAGGAT \\
\hline & cbbMI-1706R & TCCATCTTGCCRWARCCCAT \\
\hline & cbbMIII-517F & TCATYAAGAACGAYGARCCV \\
\hline & cbbMIII-1169R & TCCATYTTRCCGTARCCCAT \\
\hline & cbbMIII-1298R & AGVGCGTTCATRCCRCCRGA \\
\hline \multirow[t]{12}{*}{$h p r$} & hprI-463F & TGATCTCSGGCGGCGGCTCG \\
\hline & hprI-606F & ATCAAGGGCGGGCGGCTVGC \\
\hline & hprI-1069R & GTSACCGTSGTYTCGCCGCC \\
\hline & hprI-1071R & ANGGTSACCGTSGTYTCGCC \\
\hline & hprI-1389R & CKGAARTCRTTVACRTTGGT \\
\hline & hprII-236F & CCRTCRATGCCGTCGGTRTC \\
\hline & hprII-239F & TCGAYGCCGTCGGTGTCGSC \\
\hline & hprII-369F & TCACBGTGGTYTCGCCRCCV \\
\hline & hprII-776R & TCSGAYGTSCCSGGCGAYGA \\
\hline & hprII-851R & CAYCTGTCSGCSATCAAGGG \\
\hline & hprII-986R & CTGMTSTCBGGCGGCGGNTC \\
\hline & hprII-1239R & VTYGGCGCBGGCAAGGCCKC \\
\hline \multirow[t]{9}{*}{$m x a F$} & $\mathrm{mxaFI}-356 \mathrm{~F}$ & GTACGAGCCGAAGCAGGATC \\
\hline & mxaFI-778F & GCGATCAGTGGAAGAYCGGY \\
\hline & mxaFI-888F & CAGCGTCCGGGCGACAACAA \\
\hline & mxaFI-1323R & TGGTTGGTSGGSACGTAGAA \\
\hline & mxaFI-1447R & CCAGGCGATGAAGTTGCCCA \\
\hline & mxaFIII-269F & AGATCAATCGCGACAACGTC \\
\hline & mxaFIII-588F & CGGCAAGGAAGTGTGGAAGC \\
\hline & mxaFIII-1024R & GTCATCGACCACTTGTTGTC \\
\hline & mxaFIII-1507R & GGCTTCATCATCACGTTGGC \\
\hline \multirow[t]{4}{*}{$m s m A$} & $\mathrm{msmA}-686 \mathrm{R}$ & CCGGTTATGGTAGTGCATGA \\
\hline & msmA-854R & CCACTGGTTCGGCGGCAGAT \\
\hline & $\mathrm{msmA}-421 \mathrm{~F}$ & AAGGAAGGCTATCAGGACCG \\
\hline & $\mathrm{msmA}-202 \mathrm{~F}$ & GCATCGCCAACGAGCCGATC \\
\hline \multirow[t]{4}{*}{$\operatorname{mau} A$} & mauAI-252F & GCACTGTTCCATCGACGGCA \\
\hline & mauAI-490R & GCGCCGAAGCACCAGATGAT \\
\hline & mauAII-232F & AAGTCTTGCGATTACTGGCG \\
\hline & mauAII-526R & GACCGTGCAATGGTAGGTCA \\
\hline
\end{tabular}


Table II

Testing of new primers against reference strains known to contain the target genes. The top matches are shown from BLASTX homology interrogation of the protein database with the amino acid sequences encoded by the amplicons obtained from PCR with the primers

\begin{tabular}{|c|c|c|c|c|}
\hline Gene & DNA template organism & Primer pair & BLASTX top match & $\begin{array}{c}\text { Identity } \\
\text { (\% and amino } \\
\text { acids aligned) } \\
\text { to database } \\
\text { sequence }\end{array}$ \\
\hline \multirow[t]{2}{*}{$m x a F$ I } & \multirow[t]{2}{*}{ Methylobacterium extorquens AM1 } & $356 \mathrm{~F}+1447 \mathrm{R}$ & $\begin{array}{l}\text { PQQ-dependent dehydrogenase } \\
\text { M. extorquens PA1 (ZP_02054561) }\end{array}$ & $99(248 / 250)$ \\
\hline & & $888 \mathrm{~F}+1323 \mathrm{R}$ & $\begin{array}{l}\text { PQQ-dependent dehydrogenase } \\
\text { M. extorquens PA1 (ZP_02054561) }\end{array}$ & $100(147 / 147)$ \\
\hline \multirow[t]{2}{*}{$m x a F$ III } & \multirow[t]{2}{*}{ Xanthomonas campestris pv campestris } & $588 \mathrm{~F}+1024 \mathrm{R}$ & $\begin{array}{l}\text { MDH heavy chain, X. campestris } \\
\text { pv campestris ATCC } 33913 \text { (NP_638828) }\end{array}$ & $100(151 / 151)$ \\
\hline & & $269 \mathrm{~F}+1507 \mathrm{R}$ & $\begin{array}{l}\text { MDH heavy chain, X. campestris } \\
\text { pv campestris ATCC } 33913 \text { (NP_638828) }\end{array}$ & $99(283 / 285)$ \\
\hline \multirow[t]{2}{*}{$h p r \mathrm{I}$} & \multirow[t]{2}{*}{ Polaromonas naphthalenivorans CJ2 } & $606 \mathrm{~F}+1071 \mathrm{R}$ & $\begin{array}{l}\text { Hydroxypyruvate reductase } \\
\text { P. naphthalenivorans CJ2 (YP_981256) }\end{array}$ & $100(155 / 155)$ \\
\hline & & $606 \mathrm{~F}+1389 \mathrm{R}$ & $\begin{array}{l}\text { Hydroxypyruvate reductase } \\
\text { P. naphthalenivorans CJ2 (YP_981256) }\end{array}$ & $99(255 / 256)$ \\
\hline \multirow[t]{2}{*}{ hpr II } & \multirow[t]{2}{*}{ Ralstonia eutropha $\mathrm{H} 16$} & $236 \mathrm{~F}+1239 \mathrm{R}$ & $\begin{array}{l}\text { Hydroxypyruvate reductase } \\
\text { R. eutropha H16 (YP_728027) }\end{array}$ & $100(301 / 301)$ \\
\hline & & $369 \mathrm{~F}+776 \mathrm{R}$ & $\begin{array}{l}\text { Hydroxypyruvate reductase } \\
\text { R. eutropha H16 (YP_728027) }\end{array}$ & $99(132 / 133)$ \\
\hline \multirow[t]{2}{*}{ cbbL I } & \multirow[t]{2}{*}{ Burkholderia xenovorans LB400 } & $763 \mathrm{~F}+1331 \mathrm{R}$ & RuBisCO B. xenovorans LB400 (YP_552888) & $99(194 / 195)$ \\
\hline & & $310 \mathrm{~F}+1331 \mathrm{R}$ & RuBisCO B. xenovorans LB400 (YP_552888) & $100(304 / 304)$ \\
\hline$c b b L \mathrm{II}$ & Ralstonia eutropha $\mathrm{H} 16$ & $446 \mathrm{~F}-1254 \mathrm{R}$ & RuBisCO R. eutropha H16 (YP_840914) & $100(238 / 238)$ \\
\hline \multirow[t]{2}{*}{$c b b L$ III } & \multirow[t]{2}{*}{ Methylococcus capsulatus Bath } & $615 \mathrm{~F}+909 \mathrm{R}$ & RuBisCO M. capsulatus Bath (YP_115143) & $100(104 / 104)$ \\
\hline & & $354 \mathrm{~F}+909 \mathrm{R}$ & RuBisCO M. capsulatus Bath (YP_115143) & $100(189 / 189)$ \\
\hline \multirow[t]{2}{*}{$c b b M \mathrm{I}$} & \multirow[t]{2}{*}{ Rhodobacter sphaeroides 2.4 .1} & $899 \mathrm{~F}+1706 \mathrm{R}$ & $\begin{array}{l}\text { RuBisCO large chain form II } \\
\text { R. sphaeroides 2.4.1 (YP_354780) }\end{array}$ & $99(233 / 234)$ \\
\hline & & $1061 \mathrm{~F}+1472 \mathrm{R}$ & $\begin{array}{l}\text { RuBisCO large chain form II } \\
\text { R. sphaeroides 2.4.1 (YP_354780) }\end{array}$ & $99(141 / 142)$ \\
\hline \multirow[t]{2}{*}{$c b b M$ II } & \multirow[t]{2}{*}{ Polaromonas naphthalenivorans CJ2 } & $427 \mathrm{~F}+1054 \mathrm{R}$ & RuBisCO P. naphthalenivorans CJ2 (YP_982208 & $100(183 / 183)$ \\
\hline & & $811 \mathrm{~F}+1054 \mathrm{R}$ & RuBisCO P. naphthalenivorans CJ2 (YP_982208 & $100(87 / 87)$ \\
\hline \multirow[t]{2}{*}{$c b b M$ III } & \multirow[t]{2}{*}{ Thiomicrospira kuenenii } & $517 \mathrm{~F}+1169 \mathrm{R}$ & $\begin{array}{l}\text { RuBisCO large subunit form II } \\
\text { T. kuenenii (ABC55010) }\end{array}$ & $100(212 / 212)$ \\
\hline & & $517 \mathrm{~F}+1298 \mathrm{R}$ & $\begin{array}{l}\text { RuBisCO large subunit form II } \\
\text { T. kuenenii (ABC55010) }\end{array}$ & $100(166 / 166)$ \\
\hline $\operatorname{mauA} \mathrm{I}$ & Methylobacterium extorquens AM1 & $252 \mathrm{~F}-490 \mathrm{R}$ & $\begin{array}{l}\text { Methylamine dehydrogenase } \\
\text { light chain, M. chloromethanicum } \\
\text { CM4 (ZP_02059240) }\end{array}$ & $100(62 / 62)$ \\
\hline mauA II & Methylobacillus flagellatus KT & $232 \mathrm{~F}+526 \mathrm{R}$ & $\begin{array}{l}\text { MauA (methylamine dehydrogenase small subunit) } \\
\text { M. flagellatus KT (AAF03760) }\end{array}$ & $100(91 / 91)$ \\
\hline$m s m A$ & Afipia felis & $202 \mathrm{~F}+854 \mathrm{R}$ & $\begin{array}{l}\text { Methanesulfonate monooxygenase } \\
\text { (hydroxylase alpha subunit) } \\
\text { Afipia felis 25E1 (ABO41866) }\end{array}$ & $100(146 / 146)$ \\
\hline & & $421 \mathrm{~F}+686 \mathrm{R}$ & $\begin{array}{l}\text { Methanesulfonate monooxygenase } \\
\text { (hydroxylase alpha subunit) } \\
\text { Afipia felis 25E1 (ABO41866) }\end{array}$ & $100(83 / 83)$ \\
\hline
\end{tabular}


Table III

PCR amplification of $m x a F, h p r, c b b L$ and $c b b M$ genes in three mouth isolates and six known methylotrophic or autotrophic strains

\begin{tabular}{|c|c|c|c|c|c|c|c|c|c|}
\hline \multirow[b]{2}{*}{ Primers } & \multicolumn{9}{|c|}{ Strains } \\
\hline & $\begin{array}{c}\text { Pseudo- } \\
\text { monas } \\
\text { NaF-B-1 }\end{array}$ & $\begin{array}{l}\text { R. pickettii } \\
\text { MMA-BI-3 }\end{array}$ & $\begin{array}{c}\text { Methylo- } \\
\text { bacterium } \\
\text { MMA-CI-1 }\end{array}$ & $\begin{array}{c}\text { Amino- } \\
\text { becter } \\
\text { amino- } \\
\text { vorans } \\
\text { MA }\end{array}$ & $\begin{array}{l}\text { Xantho- } \\
\text { bacter } \\
\text { tagetidis } \\
\text { TagT2C }\end{array}$ & $\begin{array}{l}\text { Methylo- } \\
\text { cella } \\
\text { silvestris } \\
\text { BL2 }\end{array}$ & $\begin{array}{l}\text { Methylo- } \\
\text { cystis } \\
\text { sporium } 5\end{array}$ & $\begin{array}{c}\text { Methylo- } \\
\text { cystis } \\
\text { parvus } \\
\text { OBBP }\end{array}$ & $\begin{array}{l}\text { Methylo- } \\
\text { sinus } \\
\text { tricho- } \\
\text { sporium } \\
\text { OB3b }\end{array}$ \\
\hline$m x a F 356 \mathrm{~F}+1447 \mathrm{R}$ & - & - & + & - & - & + & - & - & + \\
\hline$m x a F 778 \mathrm{~F}+1323 \mathrm{R}$ & + & + & $\mathrm{nd}^{\mathrm{a}}$ & - & - & + & + & - & + \\
\hline$m x a F 888 \mathrm{~F}+1323 \mathrm{R}$ & - & - & nd & + & - & + & - & - & - \\
\hline$m x a F 1003 \mathrm{~F}+1555 \mathrm{R}^{\mathrm{b}}$ & - & - & + & - & - & + & + & + & + \\
\hline$h p r 463 \mathrm{~F}+1069 \mathrm{R}$ & - & + & + & + & - & + & - & - & - \\
\hline$h p r 239 \mathrm{~F}+851 \mathrm{R}$ & + & - & - & - & - & + & - & - & - \\
\hline$h p r 239 \mathrm{~F}+986 \mathrm{R}$ & + & - & - & - & - & - & - & - & - \\
\hline$c b b L 763 \mathrm{~F}+1331 \mathrm{R}$ & - & - & - & nd & - & + & nd & nd & nd \\
\hline$c b b L 446 \mathrm{~F}+1254 \mathrm{R}$ & - & - & - & nd & + & + & nd & nd & nd \\
\hline
\end{tabular}

${ }^{a}$ nd not determined

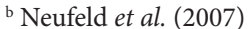

methylamine oxidase operates in Gram-positive organisms (Chistoserdova et al., 2009).

The five Proteobacteria were tested with 9, 3 and 9 primer pairs for $c b b L$ I, $c b b L$ II, and $c b b L$ III, 7 and 5 pairs for $c b b M$ I and $c b b M$ II, and 6 pairs for $c b b M$ III. All PCRs were run at an annealing temperature of $54^{\circ} \mathrm{C}$, as well as $45-57^{\circ} \mathrm{C}$ for $c b b L$, and 50 and $57^{\circ} \mathrm{C}$ for $c b b M$. No PCR products were obtained from any of the five strains: the absence of the RuBisCO genes under all the PCR conditions was consistent with none of the strains having been shown to be autotrophic.

Several pairs of primers were tested for $h p r I$ (4 pairs), hpr II (7), mxaF I (8), mxaF II (2), mauA (1) and $m s m A$ (2), with an annealing temperature of $54^{\circ} \mathrm{C}$. Predicted products were obtained with $m x a F$ and $h p r$ primers for three strains (NaF-B-1, MMA-BI-3 and MMA-C-1; Table III). The PCR products from Pseudomonas sp. NaF-B-1 and Ralstonia pickettii MMA-BI-3 (mxaF II 778F+1323R), Methylobacterium sp. MMA-CI-1 (mxaFI $356 \mathrm{~F}+1447 \mathrm{R}$ and $m x a F$ II $1003 \mathrm{~F}+1555 \mathrm{R})$, Ralstonia picketti and the Methylobacterium strain (hpr I 463F+1069R), and the Pseudomonas strain (with $h p r$ II $239 \mathrm{~F}+986 \mathrm{R}$ ) were sequenced, and in all cases identified as the expected sequences (Table IV). These results were consistent with the reported enzyme activities (Hung et al., 2011).

No PCR products were obtained from any of the five proteobacterial strains for the mauA or $m s m A$ genes. All the strains were known to grow on MSA and MMA (Hung et al., 2011), so the apparent absence of $m s m A$ and mauA genes could mean that satisfactory PCR conditions had not been achieved, or might indicate that novel enzymes were involved. It is known, for example, that methylamine metabolism in Rhodopseudomonas capsulata, Methylovorus mays and Methylocella silvestris involves glutamine synthetase (GS) to produce $\gamma$-glutamylmethylamide (Yoch et al., 1983; Yamamoto et al., 2008; Chen et al., 2010a), while N-methylglutamate synthase and $\mathrm{N}$-methylglutamate dehydrogenase have been proposed as alternatives in Methyloversatilis universalis FAM5 (Chistoserdova et al., 2009). A recent study of a lake habitat also failed to detect the mauA gene in DNA from methylamine-enriched populations (Antony et al., 2010), consistent with the existence of diverse dissimilatory systems.

In the case of the Achromobacter strain (NaF-BI-3), the database genome sequence was available for Achromobacter xylosoxidans strain A8, which contains putative genes for mauABDE (NC_014640). BLASTP of the encoded MauA amino acid sequence showed only 43-48\% identity to the MauA sequences of Methylacidiphilium infernorum, Methylobacillus flagellatus, Methylobacterium extorquens and Paracoccus denitrificans shown in Fig. 4. It was surprising that the Achromobacter genome MauA sequence showed essentially the same low similarity to all four of these sequences, suggesting it was actually close to none of them. In contrast, the reference sequences tested showed $86-91 \%$ amino acid sequence identity to those of neighboring species (e.g. $P$. denitrificans/H. sulfonivorans; $M$. flagellatus/M. alcalica; and M. extorquens/H. sulfonivorans), whereas identity between more remote pairs, such as M.infernorum/M. alcalica and M. flagellatus/P. denitrificans, showed lower sequence similarities of $40 \%$ and $66 \%$. Failure to detect the mauA gene in Achromobacter strain NaF-BI-3 thus suggested that the gene differs sufficiently from the known proteobacterial genes not to be detected by the primers under the conditions used. 
Table IV

TBLASTX homology search of the protein database for PCR products obtained from three mouth isolates and six known methylotrophic strains using functional primer sets designed in this study.

\begin{tabular}{|c|c|c|c|c|}
\hline Gene & Template & Primer pair & TBLASTX & $\begin{array}{c}\% \text { identity } \\
\text { (amino acid match) }\end{array}$ \\
\hline \multirow[t]{12}{*}{$m x a F$} & Pseudomonas sp. NaF-B-1 & $778 \mathrm{~F}+1323 \mathrm{R}$ & $\begin{array}{l}\text { PQQ-dependent dehydrogenase } \\
\text { Pseudomonas mendocina ymp (CP000680) }\end{array}$ & $\begin{array}{l}99 \\
136 / 138\end{array}$ \\
\hline & Ralstonia pickettii MMA-BI-3 & $778 \mathrm{~F}+1323 \mathrm{R}$ & $\begin{array}{l}\text { PQQ-dependent dehydrogenase } \\
\text { Ralstonia pickettii 12J (YP_001900058) }\end{array}$ & $\begin{array}{l}100 \\
128 / 128\end{array}$ \\
\hline & Methylobacterium sp. MMA-CI-1 & $356 \mathrm{~F}+1447 \mathrm{R}$ & $\begin{array}{l}\text { Methanol dehydrogenase subunit } 1 \\
\text { Methylobacterium extorquens DM4 (YP_003070571) }\end{array}$ & $\begin{array}{l}99 \\
146 / 147\end{array}$ \\
\hline & Aminobacter aminovorans MA & $888 \mathrm{~F}+1323 \mathrm{R}$ & $\begin{array}{l}\text { PQQ-dependent dehydrogenase } \\
\text { Xanthobacter autotrophicus Py2 (CP000781) }\end{array}$ & $\begin{array}{l}80 \\
47 / 59\end{array}$ \\
\hline & Methylobacterium sp. MMA-CI-1 & $1003 \mathrm{~F}+1555 \mathrm{R}^{\mathrm{a}}$ & $\begin{array}{l}\text { Methanol dehydrogenase subunit } 1 \\
\text { Methylobacterium extorquens DM4 (YP_003070571) }\end{array}$ & $\begin{array}{l}99 \\
173 / 174\end{array}$ \\
\hline & Methylocella silvestris BL2 & $356 \mathrm{~F}+1447 \mathrm{R}$ & $\begin{array}{l}\text { PQQ-dependent dehydrogenase } \\
\text { Methylocella silvestris BL2 (CP001280) }\end{array}$ & $\begin{array}{l}100 \\
43 / 43\end{array}$ \\
\hline & & $1003 \mathrm{~F}+1555 \mathrm{R}^{\mathrm{a}}$ & $\begin{array}{l}\text { PQQ-dependent dehydrogenase } \\
\text { Methylocella silvestris BL2 (CP001280) }\end{array}$ & $\begin{array}{l}100 \\
139 / 139\end{array}$ \\
\hline & Methylocystis sporium strain 5 & $778 \mathrm{~F}+1323 \mathrm{R}$ & $\begin{array}{l}\text { PQQ-dependent dehydrogenase } \\
\text { Methylobacterium nodulans ORS } 2060 \text { (CP001349) }\end{array}$ & $\begin{array}{l}100 \\
148 / 148\end{array}$ \\
\hline & & $1003 \mathrm{~F}+1555 \mathrm{R}$ & $\begin{array}{l}\text { Methanol dehydrogenase alpha subunit } \\
\text { Methylosinus sporium (AJ459083) }\end{array}$ & $\begin{array}{l}85 \\
90 / 106\end{array}$ \\
\hline & Methylocystis parvus $O B B P$ & $1003 \mathrm{~F}+1555 \mathrm{R}^{\mathrm{a}}$ & $\begin{array}{l}\text { Methanol dehydrogenase alpha subunit } \\
\text { Methylocystis sp. KS12 (AJ459094) }\end{array}$ & $\begin{array}{l}99 \\
144 / 145\end{array}$ \\
\hline & Methylosinus trichosporium OB3b & $\begin{array}{l}356 \mathrm{~F}+1447 \mathrm{R} \\
778 \mathrm{~F}+1323 \mathrm{R}\end{array}$ & $\begin{array}{l}\text { PQQ-dependent dehydrogenase } \\
\text { Methylobacterium sp. 4-46 (СР000943) }\end{array}$ & $\begin{array}{l}81 \\
142 / 176\end{array}$ \\
\hline & Methylosinus trichosporium OB3b & $1003 \mathrm{~F}+1555 \mathrm{R}^{\mathrm{a}}$ & $\begin{array}{l}\text { Methanol dehydrogenase alpha subunit } \\
\text { Methylosinus trichosporium (AJ459058) }\end{array}$ & $\begin{array}{l}99 \\
159 / 160\end{array}$ \\
\hline \multirow[t]{5}{*}{$h p r$} & Ralstonia pickettii MMA-BI-3 & $463 \mathrm{~F}+1069 \mathrm{R}$ & $\begin{array}{l}\text { Hydroxypyruvate reductase } \\
\text { Ralstonia eutropha H16 (AM260479) }\end{array}$ & $\begin{array}{l}100 \\
163 / 163\end{array}$ \\
\hline & Methylobacterium sp. MMA-CI-1 & $463 \mathrm{~F}+1069 \mathrm{R}$ & $\begin{array}{l}\text { Hydroxypyruvate reductase } \\
\text { Methylobacterium populi BJ001 (ACB82755) }\end{array}$ & $\begin{array}{l}98 \\
165 / 168\end{array}$ \\
\hline & Pseudomonas sp. NaF-B-1 & $236 \mathrm{~F}+986 \mathrm{R}$ & $\begin{array}{l}\text { Hydroxypyruvate reductase } \\
\text { Pseudomonas mendocina ymp (YP_001188259) }\end{array}$ & $\begin{array}{l}100 \\
168 / 168\end{array}$ \\
\hline & Aminobacter aminovorans MA & $463 F+1069 R$ & $\begin{array}{l}\text { mlr5144 (hypothetical protein BAB51643) } \\
\text { Mesorhizobium loti MAFF303099 (BA000012) }\end{array}$ & $\begin{array}{l}82 \\
136 / 165 \\
\end{array}$ \\
\hline & Methylocella silvestris BL2 & $\begin{array}{l}463 \mathrm{~F}+1069 \mathrm{R} \\
\text { and } 239 \mathrm{~F}+851\end{array}$ & $\begin{array}{l}\text { Hydroxypyruvate reductase } \\
\text { Methylocella silvestris BL2 (ACK50662) }\end{array}$ & $\begin{array}{l}100 \\
122 / 122 \\
\end{array}$ \\
\hline$c b b L$ & Xanthobacter tagetidis TagT2C & $446 \mathrm{~F}+1254 \mathrm{R}$ & $\begin{array}{l}\text { Ribulose bisphosphate carboxylase } \\
\text { Xanthobacter flavus (X17252) }\end{array}$ & $\begin{array}{l}98 \\
184 / 188\end{array}$ \\
\hline$c b b L$ & Methylocella silvestris BL2 & $\begin{array}{l}763 \mathrm{~F}+1331 \mathrm{R} \\
\text { and } 446 \mathrm{~F}+1254 \mathrm{R}\end{array}$ & $\begin{array}{l}\text { Ribulose bisphosphate carboxylase } \\
\text { Methylocella silvestris BL2 (CP001280) }\end{array}$ & $\begin{array}{l}100 \\
236 / 236\end{array}$ \\
\hline
\end{tabular}

${ }^{a}$ Neufeld et al. (2007)

A complete genome sequence was also available for a Klebsiella pneumoniae strain (NC_012731), enabling comparison with the mouth strain of Klebsiella (M-AI-2), in which mxaF, mauA and $h p r$ were not detected. The Klebsiella genome contained no genes annotated as either $\mathrm{MDH}$ or $\mathrm{MADH}$, suggesting the absence of these genes also from strain M-AI-2. The genome contained genes encoding nine alcohol dehydrogenases, but none showed any identity to the Methylobacterium mxaF gene. A gene encoding a putative HPR was 
present (KP1_2293), and the encoded protein for this gene (YP_002919048; 419 amino acids) was compared by BLASTP with the amino acid sequences for four of the organisms shown in Fig. 3 (Polaromonas, Pseudoalteromonas, Ralstonia H16, and Roseobacter). It showed no significant similarity to the Polaromonas sequence, and negligible similarity to the other three, with only 6-10 aligned amino acids. This supported the view that the Klebsiella strain did not contain a typical hpr gene, detectable with the primers used.

Testing the primers with strains of known methylotrophic and autotrophic Bacteria. DNA from six methylotrophic or autotrophic strains was probed with the mxaF, $h p r$ and $c b b L$ primers (Table III), and one or more of the target genes were detected in all of the strains. Sequencing these amplicons revealed identity to the expected gene products (Table IV). The positive 'hits' for cbbL, hpr and mxaF to Methylocella silvestris BL2 were obtained before publication of the genome sequence of this organism (Chen et al., 2010b), but were then shown to match the relevant loci in the genome, including confirming the presence of $\mathrm{RuBisCO}$ genes in this facultatively methanotrophic organism. Finding $c b b L$ in Xanthobacter tagetidis was expected as it, like other Xanthobacter species, grew autotrophically with methanol as the energy source (Meijer et al., 1990; Padden etal., 1997), and was consistent with the apparent absence of $h p r$. That strain grew weakly on methanol, so the failure to detect $m x a F$ might indicate absence of the expected PQQ MDH. It was interesting that the product for Aminobacter aminovorans, using $h p r$ I primers $463 \mathrm{~F}+1069 \mathrm{R}$ showed $82 \%$ sequence identity to a hypothetical protein (mlr 5144; BAB51643) in the complete genome of a Mesorhizobium loti strain. The genome does not contain a gene annotated as hpr for this strain but this result suggests that the gene is present in the Mesorhizobium loti strain, and subjecting the BAB51643 amino acid sequence to BLASTP against seven authentic Hpr sequences gave partial sequence matches of $29-42 \%$.

Conclusions. Our study provides evidence of significant diversity among the nucleotide and encoded amino acid sequences for essential genes of methylotrophy and autotrophy. While some sequences correlate with the proteobacterial phylogeny, some show clear evidence of horizontal gene transfer, thereby crossing the phylogenetic boundaries. Genes identified in the genomes of some genera (e.g. hpr in Klebsiella, mauA in Achromobacter) appeared to encode as yet uncharacterized novel proteins.

Our study has provided a set of novel primers for genes important in methylotrophy and autotrophy, which detected the target genes in reference strains and in phylogenetically diverse groups of methylotrophic strains for the first time, confirming their potential use- fulness in future studies with Proteobacteria in pure culture or in consortia in natural environments. Rapid and inexpensive next generation genome sequencing may reduce the need for the separate detection of specific genes in pure cultures of Bacteria, although detection with appropriate primers will still be the minimum-cost method of choice when large numbers of isolates are to be tested. The use of specific primers will continue to be needed for the detection of functional genes in heterogeneous environmental samples. In this respect, the primers for mauA have already been applied successfully to demonstrate methylamine-users in environmental samples of the microbial mat from Movile Cave, Romania (D. Wischer, R. Boden, J.C. Murrell, personal communication). For maximum likelihood of detecting possibly variant forms of genes, such as $h p r$, mauA, and $m x a \mathrm{~F}$, it is advisable to use more than one pair of primers when probing target DNA preparations from pure cultures or environmental samples. It is clear that work is also needed to develop a range of primers for the detection of the enzymes that enable methylotrophy in Actinobacteria.

\section{Acknowledgement}

Professor Colin Murrell is thanked for the gift of six of the test strains, and for his support of this collaboration between King's College London and the University of Warwick.

\section{Literature}

Anesti V., J. Vohra, S. Goonetilleka, I.R. McDonald, B. Sträubler, E. Stackebrandt, D.P. Kelly and A.P. Wood. 2004. Molecular detection and isolation of methylotrophic bacteria, including Methylobacterium podarium sp. nov., from the human foot microflora. Environ. Microbiol. 6: 820-830.

Anesti V., I.R. McDonald, M. Ramaswamy, W.G. Wade, D.P. Kelly and A.P. Wood. 2005. Isolation and molecular detection of methylotrophic bacteria occurring in the human mouth. Environ. Microbiol. 7: 1227-1238.

Antony C.P., D. Kumarasan, L. Ferrando, R. Boden, H. Moussard, A.F. Scavino, Y.S. Shouche and J.C. Murrell. 2010. Active methylotrophs in the sediments of Lonar Lake, a saline and alkaline ecosystem formed by meteor impact. ISME Journal 4: 147-148.

Arfman N., L. Dijkhuizen, G. Kirchhof, W. Ludwig, K-H. Schleifer, E.S. Bulygina, K.M. Chumakov, N.I. Govorukhina, Y.A. Trotsenko and D. White. 1992. Bacillus methanolicus sp. nov., a new species of thermotolerant, methanol-utilizing, endospore-forming bacteria. Int. J. Syst. Bacteriol. 42: 439-445.

Baxter N.J., J. Scanlan, P. De Marco, A.P. Wood and J.C. Murrell. 2002. Duplicate copies of genes encoding methanesulfonate monooxygenase in Marinosulfonomonas methylotropha strain TR3 and detection of methanesulfonate utilizers in the environment. Appl. Environ. Microbiol. 68: 289-296.

Boden R., E. Thomas, P. Savani, D.P. Kelly and A.P. Wood. 2008. Novel methylotrophic bacteria isolated from the River Thames (London, UK). Environ. Microbiol. 10: 3225-3236.

Chen Y., J. Scanlan, L. Song, A. Crombie, M.T. Rahman, H. Schäfer and J.C. Murrell. 2010a. $\gamma$-glutamylmethylamide is an essential intermediate for monomethylamine metabolism by Methylocella silvestris. Appl. Environ. Microbiol. 76: 4530-4537. 
Chen Y., A. Crombie, M.T. Rahman, S.N. Dedysh, W. Liesack, M.B. Stott, M. Alam, A.R. Theisen, J.C. Murrell and P.F. Dunfield. 2010b. Complete genome sequence of the aerobic methanotroph Methylocella silvestris BL2. J. Bacteriol. 192: 3840-3841.

Chistoserdov A.Y. 2001. Cloning, sequencing and mutagenesis of the genes for aromatic amino acid dehydrogenase from Alcaligenes faecalis and evolution of amine dehydrogenases. Microbiology 147: 2195-2202.

Chistoserdova L., M.G. Kalyuzhnaya and M.E. Lidstrom. 2009. The expanding world of methylotrophic metabolism. Ann. Rev. Microbiol. 63: 477-499.

De Vries G.E., N. Arfman, P. Terpstra and L. Dijkhuizen. 1992. Cloning, expression, and sequence analysis of the Bacillus methanolicus $\mathrm{C} 1$ methanol dehydrogenase gene. J. Bacteriol. 174: 5346-5353. Fesefeldt A., C.G. Gliesche. 1997. Identification of Hyphomicrobium spp using PCR-amplified fragments of the mxaF gene as a molecular marker. Syst. Appl. Microbiol. 20: 387-396.

Hall T.A. 1999 BioEdit: a user-friendly biological sequence alignment editor and analysis program for Windows 95/98/NT. Nucleic Acids Symp. Ser. 41: 95-98.

Hung W-L., W.G. Wade, R. Boden, D.P.Kelly and A.P. Wood. 2011. Facultative methylotrophs from the human oral cavity and methylotrophy in strains of Gordonia, Leifsonia and Microbacterium. Arch. Microbiol. 193: 407-417.

Kalyuzhnaya M.G., K.R. Hristova, M.E. Lidstrom and L. Chistoserdova. 2008. Characterization of a novel methanol dehydrogenase in representatives of Burkholderiales: implications for environmental detection of methylotrophy and evidence for convergent evolution. J. Bacteriol. 190: 3817-3823.

Kato N., H. Yurimoto and R.K. Thauer. 2006. The physiological role of the ribulose monophosphate pathway in bacteria and archaea. Biosci. Biotechnol. Biochem. 70: 10-21.

Kelly D.P. and J.C. Murrell. 1999. Microbial metabolism of methanesulfonic acid. Arch. Microbiol. 172: 341-348.

Kelly D.P. and A.P. Wood. 2010. Isolation and characterization of methanotrophs and methylotrophs: diversity of methylotrophic organisms and one-carbon substrates, pp. 3827-3845. In: K.N. Timmis (ed) Handbook of Hydrocarbon and Lipid Microbiology. Springer Verlag, Berlin, Heidelberg.

Lidstrom M.E. 2006. Aerobic methylotrophic prokaryotes, pp. 618634. In: Dworkin M, S. Falkow, E. Rosenberg, K-H. Schleifer and E. Stackebrandt (eds). The Prokaryotes, vol. 2. Springer-Verlag, New York.

McDonald I.R. and J.C. Murrell. 1997. The methanol dehydrogenase structural gene $m x a F$ and its use as a functional gene probe for methanotrophs and methylotrophs. Appl. Environ. Microbiol. 63: 3218-3224.

Meijer W.G., L.M. Croes, B. Jenni, L.G. Lehmicke, M.E. Lidstrom and L. Dijkhuizen. 1990. Characterization of Xanthobacter strains H4-14 and 25a and enzyme profiles after growth under autotrophic and heterotrophic conditions. Arch. Microbiol. 153: 360-367.
Moosvi S.A., C.C. Pacheco, I.R. McDonald, P. De Marco, D. Pearce, D.P. Kelly and A.P. Wood. 2005a. Isolation and properties of methanesulfonate-degrading Afipia felis from Antarctica and comparison with other strains of A. felis. Environ. Microbiol. 7: 22-33.

Moosvi S.A., I.R. McDonald, D. Pearce, D.P. Kelly and A.P. Wood. 2005b. Molecular detection and isolation from Antarctica of methylotrophic bacteria able to grow with methylated sulfur compounds. Syst. Appl. Microbiol. 28: 541-554.

Murrell J.C. and D.P. Kelly (eds). 1996. Microbiology of Atmospheric Trace Gases. Sources, Sinks and Global Change Processes. NATO Advanced Science Institutes Series, Springer-Verlag, Berlin.

Neufeld J., H. Schäfer, M.J. Cox, R. Boden, I.R. McDonald and J.C. Murrell. 2007. Stable-isotope probing implicates Methylophaga spp and novel Gammaproteobacteria in marine methanol and methylamine metabolism. ISME Journal 1: 480-491.

Padden A.N., F.A. Rainey, D.P. Kelly and A.P. Wood. 1997. Xanthobacter tagetidis sp. nov., an organism associated with Tagetes species and able to grow on substituted thiophenes. Int. J. Syst. Bacteriol. 47: 394-401.

Park H., Y.T. Ro and Y.M. Kim. 2011. MdoR is a novel positive transcriptional regulator for the oxidation of methanol in Mycobacterium sp. strain JC1. J. Bacteriol. 193: 6288-6294.

Tamura K., J. Dudley, M. Nei and S. Kumar. 2007. MEGA4: Molecular Evolutionary Genetics Analysis (MEGA) software version 4.0. Mol. Biol. Evol. 24: 1596-1599

Vorob'ev A.V., W. de Boer, L.B. Folman, P.L.E. Bodelier, N.V. Doronina, N.E. Suzina, Y.A. Trotsenko and S.N. Dedysh. 2009. Methylovirgula ligni gen. nov., sp. nov., an obligately acidophilic, facultatively methylotrophic bacterium with a highly divergent mxaF gene. Int. J. Syst. Evol. Microbiol. 59: 2538-2545.

Wood A.P. and D.P. Kelly. 2010. Skin microbiology, body odor, and methylotrophic bacteria, pp 3203-3213. In: K.N. Timmis (ed) Handbook of Hydrocarbon and Lipid Microbiology. Springer Verlag, Berlin, Heidelberg.

Wood A.P., F.J. Warren and D.P. Kelly. 2010. Methylotrophic bacteria in trimethylaminuria and bacterial vaginosis, pp. 3227-3240. In: K.N. Timmis (ed) Handbook of Hydrocarbon and Lipid Microbiology. Springer Verlag, Berlin, Heidelberg.

Yamamoto S., M. Wakayama and T. Tachiki. 2008. Cloning and expression of Methylovorus mays No. 9 gene encoding $\gamma$-glutamylmethylamide synthetase: an enzyme usable in theanine formation by coupling with the alcoholic fermentation system of baker's yeast. Biosci. Biotechnol. Biochem. 72: 101-109.

Yoch D.C., Z.M. Zhang and D.L. Claybrook. 1983. Methylamine metabolism and its role in nitrogenase "switch off" in Rhodopseudomonas capsulata. Arch. Microbiol. 134: 45-48

Yurimoto H., N. Kato and Y. Sakai. 2009 Genomic organization and biochemistry of the ribulose monophosphate pathway and its application to biotechnology. Appl. Microbiol. Biotechnol. 84: 407-416. 